\title{
Organizational Culture and Strategy Execution at Commission for University Education, Kenya
}

\author{
Edgar Sikuku Murunga1, Jane Esther Karugu² \\ ${ }^{1}$ Master of Business Administration Degree Student, Strategic Management Option, School of \\ Business, Kenyatta University, Kenya \\ ${ }^{2}$ School of Business, Kenyatta University, Kenya
}

\begin{abstract}
The effectiveness of an organization depends largely on how well the culture aligns with the organizational strategy. Boosting collaboration and fortifying culture prompts productive execution of organizational strategy. However conflict may arise between an organizational culture and the strategy, making the organizational culture a stumbling block to the success of the strategy. This study sought to find out the influence of organizational culture on strategy execution at Commission for University Education. It was guided by the following objectives; to examine the influence of consistency culture on strategy execution at Commission for University Education in Kenya; to determine the influence of mission culture on strategy execution at Commission for University Education in Kenya; to find out the influence of adaptability culture on strategy execution at Commission for University Education in Kenya and to establish the influence of involvement culture on strategy execution at Commission for University Education in Kenya. The study was guided by Denison Model and Resource Based View Theory. Descriptive research design was used in this study. The staff members at Commission for University Education formed the study's target population. Both stratified and simple random samplings were employed in this study. The study used questionnaires as the main method of collecting data. The questionnaires were structured into closed-ended questions by use of multiple choice and likert questions. Statistical Package for Social Science (SPSS) version 20 was used to enter and analyze quantitative data. Output data was presented in form of tables showing the frequency, percentage and standard deviation. Results indicated that consistency had the highest influence on strategy execution $(B=0.684)$. This was followed by involvement $(B=0.476)$ and mission $(B=0.203)$. Adaptability has the least influence on the dependent variable $(B=0.096)$. The study concludes that consistency has the highest significant influence on strategy execution. The study also concludes that involvement culture is significant in steering towards an organizations strategy execution. The study further establishes that mission culture and adaptability culture play a significant role in influencing strategy execution. The study finally concludes that organizational culture is significant in steering towards an organizations strategy execution. The study recommends that government should emphasize on the need of aligning the company mission with the operations of the organization. Companies should consider involving their employees in decision making for them to feel part of the organization.
\end{abstract}

Key Words: Organizational Culture, Mission Culture, Adaptability Culture, Consistency Culture, Involvement Culture, Strategy Execution, Commission for University Education

DOI: 10.35942/ijcab.v3iV.62

\section{Cite this Article:}

Murunga, E., \& Karugu, J. (2019). Organizational Culture and Strategy Execution at Commission for University Education, Kenya. International Journal of Current Aspects, 3(V), 76-90. https://doi.org/10.35942/ijcab.v3iV.62 


\section{Introduction}

Organization culture guides daily working relationships, communication, behavior and the distribution of class and power in a firm (Raza, Mehmood, and Sajjid, 2013). Additionally, culture is a determinate of how the organization meets objectives and behaviors associations with other stakeholders. The proper cultural qualities assist corporations quickly react to client needs or opponents activities hence making it deliberately pertinent (Linnenluecke and Griffiths, 2010). The acceptable culture is as a result of what the company needs to address outer challenges and prevail in its condition. Efficient organizational cultures are firmly identified with the business technique and hearten adjustment to the changing condition so a sound and beneficial organization can be preserved (Aryasri \& Aijaz, 2013). The organizational culture and the organizational strategy being implemented are expected to support and be consisted with each other at all times in an organization (Johnson \& Scholes, 2002). In today's business world, organizations need to check whether their culture encourages or are flexible to fit the desired organizational strategy. Systems and structures need to be changed by managers as the organizational strategy advances to fit and strengthen organizational culture that can successfully support strategy implementation (Gupta, 2011). This is necessary because managers are the implementers of the strategies hence it is their task to create an alignment between organizational culture and the strategy and maintain it (Thompson \& Strickland, 2003).

Organizational culture is the set of common rules applied overtime in an organization while coping and resolving challenges of external adaptation and internal integration (Park, Ribiere and Schulter, 2004). The common rules are usually taught to the members of the organization as the standard ways to solve the challenges. Strategy is the road map of an organization that achieves organizational advantages by configuration of resources in a challenging environment in order to meet market needs and realize stakeholders' expectations (Johnson \& Scholes, 2002). According to Thompson, Strickland \& Gamble (2009), an organization with culture that is grounded on principles, practices and behaviours required for successful strategy implementation motivates employees to perform their work in line with the strategy in place and consequently achieve efficiency and effectiveness in strategy implementation. However when a conflict arises between an organizational culture and the strategy, organizational culture impend the success of the strategy. It is noted that organizational culture is an essential characteristic known for running outstanding organizations that have achieved the strategic fit between their strategies and culture (Kotter, 2012). There are ten steps that can be followed to integrate the organizational strategy to the organizational culture. The organization must establish a vision, agree on a mission, develop key strategies to be implemented in the organization, come up with strategic goals to be achieved and institute values to hold on to. The organization is then required to share policies and procedures within the organization and ensure that the top leadership is in support of the strategy.

Thompson and Strickland (2007) noted that universally the idea and routine with regards to actualizing strategies have been held onto crosswise over different segments as it is seen to add to organizational viability towards achieving outline goals and objectives. Today, both private and public organizations are serious of the procedures of implementing strategic plans in an effort to improve their performances. According to Pearce and Robinson, (2009) organizations are dependent on their external environment. Therefore, changes occurring in the environment act as triggers to upsurge their growth or dwindle their performance. The environment strategy

performance (ESP) postulates that the environment determines the choice of a firm's conduct (strategy) which also impacts on the firm's performance (Thompson, 2008). For organizations to 
remain competitive in the dynamic, complex and unpredictable environment, successful implementation of its strategy is critical (Spender, 2014). Organizations change continually because they are open systems in constant interaction with the environment. Effective strategy implementation depends on competent personnel, effective internal organization structure, resources strength and allocation, and prevailing market conditions (Kotter, 2014).

Strategy execution is the indirect manipulation by the organization its environments' resources and market in order to realize its set objectives. It includes the utilization of structures to accomplish the firm's general goal (MacLennan, 2010). Kalali, Anvari, Pourrezat and Dastejerdi (2011) affirm that strategy execution is the interpretation of selected strategy into organization activity in order to accomplish strategic objectives and goals. Strategy execution is concerned with translation of strategy into action which is part of strategic management analysis and choice (Ibrahim, Sulaiman, Kahtani \& Abu-Jarad, 2012). According to Pearce and Robinson (2006), the process of execution requires the managerial support that will ensure all members of the organization work towards achievement of the desired goals of the strategy. Strategies ordinarily fail on execution because of the way that administrators consider execution from strategic point of view and along these lines assign it onto subordinates while they center on other greater issues. More than just strategies and a system, discipline is needed for execution to be realized. Execution includes significantly more than just strategies (Spender, 2014). Strategy execution must be coordinated into organization's system, objectives, and in particular culture. It is likewise basic for pioneers of the Organization to be profoundly required with the execution to such an extent that a case of responsibility is set. Bossidy, Charan, and Burck (2011) points that execution is tied in with completing things requires an unmistakable arrangement of practices and strategies Organizations need to ace so as to have an upper hand.

\section{Statement of the problem}

The effectiveness of an organization depends largely on how well the culture aligns with the organizational strategy. It's noted that boosting collaboration and fortifying culture prompts productive execution of organizational strategy (Musyoka, 2011). However conflict may arise between an organizational culture and the strategy, making the organizational culture a stumbling block to the success of the strategy. Korn Ferry Survey (2014) findings showed that culture is critical to organizational execution. Thus it is important to encourage the executives in different organizations to champion the alignment between organizational culture and strategy implementation. Past studies in related field have indicated contradicting results on impact of organizational culture on strategy execution. A study in Australia by Baird, Harrison and Reeve (2007) found out that a specific strategy needs a definite organizational culture. A study by Goromonzi (2016) found out that culture and strategies have a lot of importance on the performance of Commercial banks in Zimbabwe. In Kenya, Abok, Waititu, Gakure and Ragui (2013) indicate that organizational culture affects the implementation of the strategic plans. Isaboke (2015) found out that certain aspects of culture have a strong effect on the strategies of the universities. None of the studies above have focused on strategy execution at Commission for

University Education in Kenya. It is against this backdrop that this study sought to find out the organizational culture and strategy execution at Commission for University education.

\section{Research Objectives}

i. To determine the influence of mission culture on strategy execution at Commission for University Education in Kenya 
ii. To find out the influence of adaptability culture on strategy execution at Commission for University Education in Kenya

iii. To examine the influence of consistency culture on strategy execution at Commission for University Education in Kenya

iv. To establish the influence of involvement culture on strategy execution at Commission for University Education in Kenya

\section{Theoretical Review}

The study was guided by Denison Model and Resource Based View Theory.

\subsection{Denison model}

The theory was proposed by Denison's (1990) and makes four assumptions which set its basis. The organizations beliefs and values offer significance to a set of its administration performances. The dominant values and beliefs determine the actions of the management (Denison 1997). The model comprises of four main features that is adaptability, consistency, involvement and mission. Sharifirad \& Ataei, (2012) note that the model has been adopted by various organizations. The organization mission is concerned with the focus of the organization. It is the direction which the organization is taking to fulfill its long-term goals. Under mission, the model seeks to identify the organizations strategic direction $\&$ intent, goals $\&$ objectives as well as the vision (Denison, 2012). A feeling of mission gives two noteworthy impacts on an organization's running (Ashkanasy, Wilderom \& Peterson, 2011). Adaptability according to the model is about the position of the company in relation to the market. The translation of external environment demands into activities aligned with the company's goals involves change creation, client focus and organizational learning (Denison, 2012). Organizations that are high-performing can see and react to nature, clients, and re-structure and re-regulate practices and procedures that enable them to adjust (Ashkanasy, Wilderom \& Peterson, 2011). Denison model defines involvement as the alignment, engagement and capability of personnel within the organization. For involvement to be achieved the employees have to be empowered, teamwork enhanced and capability development (Denison, 2012). Involvement produces inventive ideas and plans which are then refined into a more exact pact of standards (Denison 1990). Consistency is concerned with the availability of values, systems and procedures to execute the organizations goals. Defining values through consistency is refined through agreement, core values and coordination \& integration (Denison, 2012). Consistency enables organizations to build up a plan of frameworks that make an internal structure of administration in view of consensual help (Ashkanasy, Wilderom \& Peterson, 2011). To determine the organizational culture and their impact on the strategy execution, this study took into account the influence of the culture at the Commission for University Education and how they influence strategy execution, how an organization aligns its mission, adaptability, consistency and involvement culture, determines strategy execution.

\subsection{Resource Based View Theory}

According to Hunt and Morgan (1995) the theory depends on the idea of economic lease and the perspective of the organization as an assembly of capacities. It emphasizes the firm's resources as the fundamental determinants for achieving competitive advantage (Borg \& Gall, 2009). The Resource based theory contends that organizations own resources which when subdivided, part of it makes the organization attain competitive advantage and the other leads to superior and sustainable performance (Barney, 2012). Barney (2010) further asserts that in a resource-based 
context, resources have value only if they can support efficient and effective strategy implementation. The resource must be able to add value, be rare, not easily copied (imitable) and non-substitutable to attain a sustainable competitive advantage. The organizational managers therefore have to identify the key resource which satisfies the criteria of potential resources in the competitive environment where the firm operates (Galbreath, 2005). The theory put forward three types of resources that can provide competitive advantage to firms, including, physical resources, organizational resources and human resources. According to the resource-based view; physical capital resources in an organization include the plant, machinery and finances, Organizational resources include the structures and the functions of management and human resource systems while the human capital resource are the organizational skills, judgment, intelligence, history, connections, trust and organizational culture, express administration control frameworks and pay strategies (Barney, 2012). Culture as part of human capital resources justifies the application of this theory in this study since it provides a valuable way for the researcher to think about how the organizational culture-strategy alignment is useful in achieving effectiveness in strategy execution at Commission for University Education in Kenya.

\section{Empirical Review}

An empirical review is conducted based on the study objectives. The objectives focuses on consistency culture and strategy execution, mission culture and strategy execution, adaptability culture and strategy execution, involvement culture and strategy execution . Study by Ghader and Afkhami (2014) showed a positive relationship between consistency and organizational commitment. Similarly, Hakim (2015) established that consistency had a powerful influence on organizational performance. However, Nongo and Ikyanyon (2012) findings indicated that consistency did not influence performance. A study in Nigeria conducted by Aluko (2011) inspected the multidimensional effect of culture on organizational performance. The study was carried out in textile firms in Kano, Lagos and Asaba. Analysis of data was through parametric and non-parametric measurements. Organizational performance was found to be positively significantly influenced by organizational culture (Aluko, 2011). One major gap identified in Aluko (2011) study is that the dependent variable was performance of the organization. The current study however investigated the relationship between organizational culture and strategy execution. Aluko (2011) study targeted textile firms while the current study focused on commission of university education thus filling the arising gap. In Kenya, Voi Sub-County, Mwashighadi and Kising'u (2017) evaluated the organizational culture role in performance. Descriptive design was employed with a total population being 73 people. A total of 43 respondents from commercial banks in the sub-county were sampled through stratified random sampling. From the study findings, organizational culture was found to have an influence on performance (Mwashighadi \& Kising'u, 2017). Since this study was carried out in Voi SubCounty in Kenya a gap thus arises. To fill the gap, the current study was conducted in Commission for University Education to determine the influence of organizational culture on strategy execution. Similar study was carried out by Isaboke (2015). By use of descriptive survey, the study target population was 102 workers in chosen universities in Kenya. The sampling method used was proportionate stratified sampling. Data was collected by use of questionnaires and quantitatively analyzed using SPSS. From the study results, strategy implementation was influenced by organizational culture. Dominant characteristics were found to have the strongest influence on the implementation of strategy (Isaboke, 2015). The fact that the study only involved employees in chosen institutions of higher learning develops a gap. The 
gap was filled by conducting a similar study focusing on Commission for University Education in Kenya.

Mission provides purpose and meaning by defining a social role and external goals for the organization (Denison \& Neale, 2011). Mission also gives clear direction and goals that serves to define an appropriate course of action for the origination. A Ghana study carried out by KofiPoku and Owusu-Ansah (2013) looked at the performance of banks as determined by organizational culture. The study involved a total of 296 respondents from 9 banks. The outcome of the study was that different banks related differently on organizational culture and the performance. They however showed a consistent positive significant effect of mission on the performance. Given that the study Kofi-Poku and Owusu-Ansah (2013) was conducted in banks, differing results may be indicated by other firms hence a gap. Olughor (2014) determined effectiveness of firms as influence by organizational culture in the banking sector. He employed survey design with a sample size of 200 respondents. The study employed Denison model to measure cultural traits such as mission, involvement, adaptability and consistency. Findings showed that mission had the strongest influence on the effectiveness of the firms. A gap arises as Olughor (2014) study was delimited to banking sector. To expound on that the current study wishes to conduct a study by targeting employees at the Commission for University Education in Kenya. In Pakistan, Ahmad (2012) evaluated the effect of organizational culture on execution. The point of the study was to extend the base of information and experimentally test the connection between organizational culture elements and performance. Exploratory method was used to show the impact while collecting data using questionnaires. The study further tested the relationship through correlation and regression. A positive significant relationship between culture mission and performance was identified (Ahmad, 2012). This study however tested one aspect of organizational culture-mission. This study filled the gap by including four aspects of organizational culture-mission, adaptability, involvement and consistency.

Adaptability predicts employee commitment more than any other corporate cultural variables. Employees are more committed to organizations that adapt to changing circumstances (Nongo \& Ikyanyon, 2012). Employees exhibit the highest organizational commitment when they perceive higher learning culture which includes culture of creating, acquiring, and transferring knowledge (Ghader \& Afkhami (2014). A study by Sunarsih and Mashithoh (2016) assessed the impact of organizational culture on workers' commitment. The study targeted staff in Universitas Terbuka. The sample size selected through simple random sampling was a total of 90 workers at UT Head office. Findings showed that there was positive significant correlation between adaptability and staff commitment (Sunarsih \& Mashithoh, 2016). This study however tested one aspect of organizational culture-adaptability. This study filled the gap by including other essentials of organizational culture for instance mission, involvement and consistency. The study further investigated their influence on strategy execution at Commission for University Education in Kenya. Another study based in Nigeria by Duke and Edet (2012) established a relationship between organizational culture and NGOs performance. The study population comprised of NGOs functional in the county. A total of 99 were sampled through random sampling. Analysis was conducted using OLS method. Findings revealed that organizational culture had a positive effect on performance of the NGOs (Duke \& Edet, 2012). Since the study involved NGOs in Nigeria, it is assumed that different results may be found in another organization especially in a different country. For this reason, therefore the current study aims at assessing the influence of organizational culture on strategy execution in Kenya. Mwaura and Bula (2017) aimed at determining the organizational culture effects on firm performance. The study focused on 
employees-low level, middle level and top level managers at ICPAK. Organizational culture had the following indicators; mission, adaptability, consistency and involvement. Findings indicated that the organization had mission statements and values that served as powerful guides for everyday action. Firms characterized by higher adaptability culture and consistency culture performed better (Mwaura \& Bula, 2017). As the study was limited to ICPAK only a gap occurs. To fill the gap, the current study targeted employees at Commission for University Education in Kenya. Abok et al., (2013) studied the significance of culture on strategy implementation in NGOs. From a total population of 2588 NGOs, the researcher used a sample of 258 NGOs in Nairobi. Questionnaires were used to collect data which was both qualitative and quantitative in nature. Content analysis and descriptive statistics were employed in data analysis. The study findings indicated that organizational culture affects the implementation of the strategic plans. Abok et al., (2013) was however limited to the NGOs operating in the Nairobi district hence justifies the need for the current study.

Involvement implies the cooperation of workers in their culture with the goal that they adjust their culture and work to expand the organizations performance (Robbins and Judge, 2013). If staffs of the organization are profoundly associated with their work, organizations performance increases. Nongo and Ikyanyon (2012) found a noteworthy and positive connection among involvement and duty. Workers are in this manner focused on their company when they are engaged with basic leadership. So also, Singh and Verghese (2015) explored the effect of employee strengthening. They found a huge positive connection between empowerment of employees and their commitment in the organization. In South Sudan, Akuei et al. (2016) assessed organizational culture role in realizing effectual strategy implementation. The study involved commercial banks in that country targeting top level and middle level managers. Elements of organizational culture according to the study were employees' management, leaders, dominant features and success criteria. Both explanatory and descriptive research designs were employed in the study. Findings indicated that there was no significant influence of dominant characteristics on strategy implementation. Leadership was found to positively influence strategy implementation (Akuei et al., 2016). This study however tested different aspects of organizational culture from what the current study intends. This study filled the gap by including four aspects of organizational culture-mission, adaptability, involvement and consistency.

Ofori and Atiogbe (2011) study investigated strategic planning in developing nations paying attention to public universities. The study further narrowed down to strategy implementation as a result of influences of culture in the University of Ghana. Study population was all the staff in the institution. Findings showed that the staff behaviours did not significantly influence the implementation strategy. The staff values just existed in name as administration had not successfully guaranteed that an incredible culture was comprehended and shared by all. Culture was a main impetus for strategy implementation. Additionally, findings revealed that staff participation was encouraged as an essential instrument for building and managing a functional culture. This study however tested one aspect of organizational culture-involvement. This study filled the gap by including other basics of organizational culture for example mission, involvement and consistency and their influence on strategy implementation. Goromonzi (2016) investigated the influence of culture on commercial banks performance in Zimbabwe in relation to their strategies. To measure the influence of culture on strategy, four factor, six dimensional organizational culture index as well as an eight dimensional strategy implementation index was used. The study was analyzed using simple regression and descriptive statistics while data was obtained via a questionnaire. The study findings showed that culture and strategy have a lot of 
importance on the performance of commercial banks in Zimbabwe. This study focused on commercial bank performance in Zimbabwe. The researcher intends to fill the gap by studying the effects of the organizational culture-strategy execution in Commission for University Education in Kenya.

\section{Conceptual Framework}

Figure 1 shows that the independent variable was indicated by consistency culture, mission culture, adaptability culture and involvement culture. The dependent variable was strategy execution with objectives achievement and meeting deadline as key indicators.

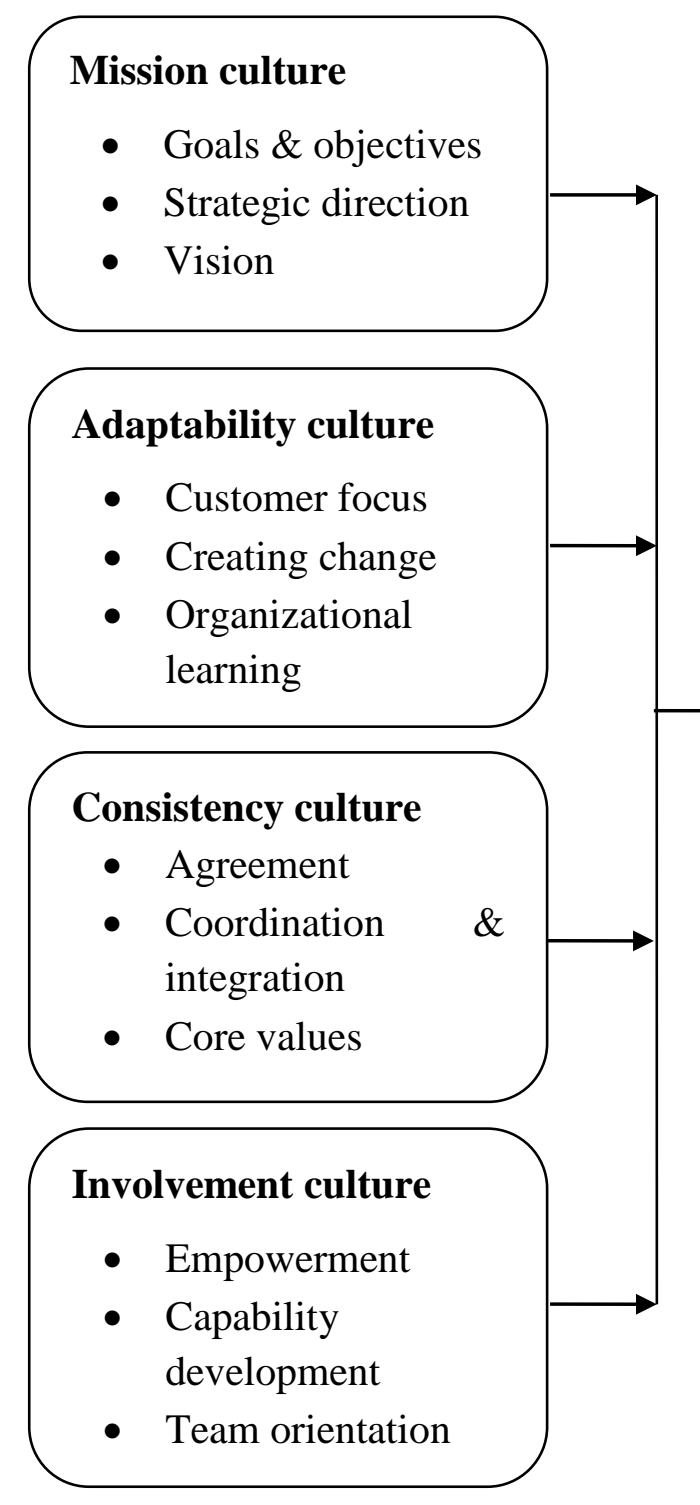

Independent Variable

Dependent Variable

Figure 1: Conceptual Framework 


\section{Research Methodology}

Descriptive research design was used in this study. Descriptive research describes the characteristics of people taking part in the study (Jackson, 2009). Through descriptive design, the researcher was able to better understand issues to do with the characteristics of people under study. The staff members at Commission for University Education formed the study's target population. As at 2018, the organization had a total of 130 staff (Commission for University Education, 2018). Both stratified and simple random samplings were employed in this study. Since there are three levels of management, stratified sampling was used to categorize them as shown in Table 3.3. The study further used simple random sampling to select individuals that participated in the study. To get a sample size the study used Krejcie and Morgan (1970) to get a sample size of 97 respondents.

Once the process of data collection was finalized the researcher went through all questionnaires to ascertain whether they were completely and accurately filled. The next stage was entering the data in statistic software by coding accordingly. In this study Statistical Package for Social Science (SPSS) version 20 was used to enter and analyze quantitative data. Output data was presented in form of tables showing the frequency, percentage and standard deviation. Multiple regression model was used to determine coefficients of the independent variables in relation to the dependent variable. The multivariate regression model for this study was; $\mathbf{y}_{\mathbf{i}}=\mathbf{B}_{\mathbf{0}}+\mathbf{B}_{1 \mathbf{1}} \mathbf{x}+$ $\mathbf{B}_{2} \mathbf{x}_{\mathbf{i} 2}+\ldots+\mathbf{B}_{\mathbf{p}} \mathbf{x}_{\mathbf{i p}}+\mathbf{E}$. Where, $\mathrm{y}_{\mathrm{i}}$ represents strategy execution, $\mathrm{x}_{\mathrm{i} 1}$ represents consistency culture, $\mathrm{x}_{\mathrm{i} 2}$ represents mission culture, $\mathrm{x}_{\mathrm{i} 3}$ represents adaptability culture, $\mathrm{x}_{\mathrm{i} 4}$ represents involvement culture, $\mathrm{B}_{0}$ is the constant, $\mathrm{B}_{1}, \mathrm{~B}_{2}, \mathrm{~B}_{3}$ and $\mathrm{B}_{4}$ are coefficients, $\mathrm{E}$ is the error term.

\section{Data Analysis}

An inferential statistic was carried out to show the association between the independent and the dependent variables. The independent variables under the study were mission culture, adaptability culture, consistency culture and involvement culture. The dependent variable on the other hand was strategy execution at CUE.

Table 1: Model summary

\begin{tabular}{|c|c|c|c|c|}
\hline Model & $\mathrm{R}$ & R Square & Adjusted R Square & $\begin{array}{l}\text { Std. Error of the } \\
\text { Estimate }\end{array}$ \\
\hline 1 & $.664^{\mathrm{a}}$ & .440 & .413 & .387 \\
\hline
\end{tabular}

The value of $\mathrm{R}$ square as shown in Table 1 is 0.440 indicating that $44 \%$ of the influencers of strategy execution are explained by the variables under study. Thus, the remaining percentage is determined by other factors other than involvement, mission, adaptability and consistency. This has an implication that strategy execution at Commission for University Education is partly influenced by organizational culture.

Table 2: ANOVA

\begin{tabular}{lllllll}
\hline Model & & Sum of Squares & df & Mean Square & F & Sig. \\
\hline 1 & Regression & 9.570 & 4 & 2.392 & 15.933 & $.000^{\mathrm{b}}$ \\
& Residual & 12.163 & 81 & .150 & & \\
& Total & 21.733 & 85 & & & \\
\hline
\end{tabular}


a. Dependent Variable: Strategy execution

b. Predictors: (Constant), Involvement, Mission, Adaptability, Consistency

The overall model was significant $(\mathrm{p}<0.05)$ in determining the relationship between the independent variables (mission, adaptability, consistency and involvement) and the dependent variable (strategy execution).

Table 3: Coefficients

\begin{tabular}{|c|c|c|c|c|c|}
\hline \multirow[t]{2}{*}{ Model } & \multicolumn{2}{|c|}{ Unstandardized Coefficients } & \multirow{2}{*}{$\begin{array}{l}\text { Standardized Coefficients } \\
\text { Beta }\end{array}$} & \multirow[t]{2}{*}{$\mathrm{t}$} & \multirow[t]{2}{*}{ Sig. } \\
\hline & $\mathrm{B}$ & Std. Error & & & \\
\hline (Constant) & 2.874 & .278 & & 10.332 & .000 \\
\hline Mission & .203 & .070 & .297 & 2.916 & .005 \\
\hline Adaptability & .096 & .064 & .153 & 1.489 & .040 \\
\hline Consistency & .684 & .116 & .752 & 5.893 & .000 \\
\hline Involvement & .476 & .087 & .751 & 5.455 & .000 \\
\hline
\end{tabular}

As shown in Table 3 , the constant is 2.874 . The $\beta$ values for mission, adaptability, consistency and involvement are $0.203,0.096,0.684$ and 0.476 in that order. The equation therefore becomes; $\mathrm{Y}=2.874+0.203 \mathrm{X}_{1}+0.096 \mathrm{X}_{2}+0.684 \mathrm{X}_{3}+0.476 \mathrm{X}_{4}+$ e. Results show that all the variables have a positive significant influence on the dependent variable (strategy execution) $(\mathrm{p}$ is less than 0.05 for all). Further results indicate that consistency has the highest influence on strategy execution $(B=0.684)$. This is followed by involvement $(B=0.476)$ and mission $(B=0.203)$. Adaptability has the least influence on the dependent variable $(B=0.096)$. The results have an implication that consistency has the greatest influence on strategy execution. Findings concur with Hakim (2015) who established that consistency had a powerful influence on organizational performance. According to Mwaura \& Bula (2017) firms characterized by higher adaptability culture and consistency culture performed better. From the study findings, it is clear that involvement culture has a positive significant influence on strategy execution. Nongo and Ikyanyon (2012) also found a noteworthy and positive connection among involvement and performance. Findings also imply that mission play a significant role in realization of an organization's strategy execution. Findings agree with Ahmad (2012) who found a positive significant relationship between culture mission and performance. Finally, study results have an implication that adaptability has the least influence on organizations' strategy execution. The findings correspond to Sunarsih and Mashithoh (2016) who showed that there was positive significant correlation between adaptability and staff commitment.

\section{Conclusion}

The study concludes that consistency has the highest significant influence on strategy execution. Attaining a win-win solution to employees' disagreement and having a clear accord regarding the acceptable or unacceptable of doing things play a big role in attaining strategy execution within an organization. The study also concludes that it is important to have managers as role models for the employees. When employees have a prior knowledge of what is expected of them, they become consistent. Employees should also be guided by set of ethical codes and values. The study also concludes that involvement culture is significant in steering towards an organizations strategy execution. The involvement culture is necessitated by incessant investment for developing the workers skills, the employees' capabilities and delegation. It can be concluded that organization should consider having decision making is done at all levels, make the 
employees know that their contribution is valued and provide great avenues of sharing information amongst employees. Strategy execution is further made possible by spirit of cooperation across all departments and working as a team. The study further establishes that mission culture and adaptability culture play a significant role in influencing strategy execution. Management needs to set realistic and ambitious goals and track its progress against the laid-out goals. Employees' vision should be in line with the company goals. The mission should be meaningful and understandable to all employees. Customers' comments should be involved in decision making. The study also concludes that the organization should incessantly adapt improved ways of working and departments should work together to create change by considering competitors actions. Finally, the study establishes that organizations should encourage innovation, learning as well as view failures as opportunities.

\section{Recommendations of the Study}

The study has come up with the following recommendations in view of the study findings:

i. The government should emphasize on the need of aligning the company mission with the operations of the organization. This may help the employees in understanding the company goals and objectives and resultantly play a role in achieving the targets.

ii. Public companies should consider involving their employees in decision making for them to feel part of the organization.

iii. Companies, both public and private should create a culture that allows for teamwork and cooperation among workers and across departments in their organizations.

iv. The general public who are the consumers of services offered by public companies need to be engaged before final decision making can take place. Their contribution in form of comments they give needs not to be ignored.

\section{REFERENCES}

Abok, A., Waititu, A., Gakure, R., \& Ragui M. (2013). Culture's role in the implementation of strategic plans in non-governmental organizations in Kenya. Prime Journal of Social Science, Vol. 2(4), pp. 291-295,

Achua, C. F. \& Lussier, N. R (2013) Effective Leadership 5th International Edition. Canada: South Western Cengage Learning.

Aluko, M. A. O. (2011). The Impact of Culture on Organizational Performance in Selected Textile Firms in Nigeria. Nordic Journal of African Studies 12(2): 164-179

Anderson, E. (2012) "How to motivate without money." Management Today 1 Mar. 2012: 42.Expanded Academic ASAP. Web. 1 Oct. 2012.

Armstrong, M.\& Baron, A. (1998). Performance Management: The New Realities. London: Institute of Personnel and Development

Ashkanasy, N. M., Wilderom, C., \& Peterson, M. F. (2011). The handbook of organizational culture and climate.

Bakker, A.B., Schaufeli, W.B., Leiter, M.P. \& Taris, T.W. (2008), -Work engagement: an emerging concept in occupational health psychologyll, Work \& Stress, Vol. 22, pp.187200.

Blois W., Cook C. W. \& HunSaker P. L (2007). Management and Organizational Behaviour. $2^{\text {nd }}$ Ed. New York: McGraw- Hill Education.

Bolo, Z. A., Wandera, R. W., Imaita, I., \& K'Obonyo, P. (2010). Challenges facing the 
Implementation of differentiation strategy in the operations of the Mumias Sugar Company Limited. A conference paper presented at The $1^{\text {st }}$ KIM Conference on Management: A Journal of The KIM School of Management.

Campbell, J. P. (1990). Modeling the performance prediction problem in industrial and Organizational psychology. In M. D. Dunnette \& L. M. Hough (Eds.), Handbook of Industrial and Organizational Psychology (pp. 687-732). Palo Alto, CA: Consulting Psychologists Press, Inc.;

Campbell, J. P., McCloy, R. A., Oppler, S. H., \& Sager, C. E. (1993). A Theory of Performance: In N. Schmitt \& W. C. Borman (Eds.), Personnel Selection in Organizations (pp. 35-70). San Francisco: Jossey-Bass.

Cascio, W. F. (2006). Managing Human Resources: Productivity, Quality of Life, Profits. McGraw- Hill Irwin.

Case, J. (1996) "Corporate culture." Inc. Nov. 1996: 42. Expanded Academic ASAP. Web. 2 Feb. 2013.

Chegini, M.G. (2010). The relationship between organizational culture and staff productivity public organizations Journal of Social Sciences 6 (1): 127-129.

Cheung, S., Wong, P. \& Wu, A. (2011). Towards an Organizational Culture Framework in Construction. International Journal of Project Management 29(1) pp.33-44

Commission for University Education, (2018). http://www.cue.or.ke/index.php/downloads-1

Dacin, M., Munir, K. \& Tracey, P. (2010) Formal Dinning at Cambridge Colleges: Linking Ritual Performance and Institutional Maintenance. Academy of Management Journal 53(6) pp 1393-1418

Deal, T. E \& Kennedy, A.A (1982). Corporate Cultures. The Rites and Rituals of Corporate Life. Addison-Wesley.

Denison, D. (2009). Denison Organization culture Model, Lausanne, Switzerland. Available at http://www.linkageinc.cm/offerings/Pages/Denison.aspx. Accessed on July 10, 2018.

Denison, D. R. (1990). Corporate culture and organizational effectiveness. John Wiley \& Sons, Inc.

Denison, D. R. (1997). Corporate culture and organizational effectiveness. Ann Arbor, MI: Denison Consulting.

Denison, D. R. (2012). Leading culture change in global organizations: Aligning culture and strategy. San Francisco, CA: Jossey-Bass.

Denison, D., Janovics, J., Young, J. \& Cho, H. (2006). Diagnosing Organizational Culture. International Institute for Management Development pp 1-39.

Denison, D.R. (1990), Corporate Culture and Organizational Effectiveness. John Wiley: New York, NY.

DeWitt, D. (2010) Simple Ways to Improve Employee Job Performance. Available at http://www.helium.com/items. Accessed on July 10, 2018.

Dodek, P., Cahill, N.E.,\& Heyland, D.K. (2010). The Relationship between Organizational Culture and Implementation of Clinical Practice Guidelines: a Narrative Review, Journal of Parental and Enteral Nutrition, Vol. 34 No. 6 pp. 669-674.

Duke J., and Edet G. (2012). Organizational Culture as a Determinant of Non-Governmental Organization Performance: Primer Evidence from Nigeria. International Business and Management, Vol. 4, No. 1, 2012, pp. 66-75

Forest, D. R.\& David, F. B. (2003). It's Time to Redraft Your Mission Statement." Journal of Business Strategy, pp 114-123. 
Gallagher, A., \& Brown, P. (2007). Predicting Corporate Performance from Organizational Culture. Journal of Management Studies, 29(3), 83-798.

Ghader, S. and Afkhami M.(2014).Effect of Organizational Culture on Organizational Silence;3(10);3306-3313

Giberson, T., Resick, C., Dickson, M., Mitchelson, J., Randall, K. \& Clark,M. (2009). Leadership and Organizational Culture: Linking CEO Characteristics to Cultural Values. Journal of Business and Psychology, 24(2), pp123-137

Gill, J.\& Johnson, P. (2002). Research Methods for Managers. London: Sage.

Gordon, C. (2008). Cashing in on corporate culture. Available at http://www.camagazine.com/archives/print-edition/2008/ Accessed on July 10, 2018.

Isaboke., C. (2015). Influence of Organization Culture on Strategy Implementation in Selected Universities in Kenya. International Journal of Economics, Commerce and Management, 3 (9), pp 806-820

Jackson, S.L. (2009). Research Methods and Statistics: A Critical Thinking Approach 3rd edition. Belmont, CA: Wadsworth.

Jones, G. R. (2003). Organizational Theory, Design, and Change. Upper Saddle River: Prentice Hall. 91

Kandula, S. R. (2006). Performance Management. New Delhi: Prentice Hall of India private Limited.

Khan, A. (2005). Matching People with Organization culture. Business Management Group Journal ; 23(4):12.

Kofi-Poku M., and Owusu-Ansah W. (2013). Organizational Culture and Organizational Performance: Empirical Evidence from the Banking Industry in Ghana. International Journal of Business, Humanities and Technology, 3(1) pp 95-107

Kohtamäki, V., \& M. Salmela-Mattila. (2009). Balancing organizational differentiation and integration: Finnish University reform. Paper presented in the 31st Annual EAIR Forum in Vilnius, Lithuania. 23-26 August, 2009.

Kotter, J., \& Heskett, J. (2010). Corporate culture and performance. Free press.

Kurstedt, H. A., Jr., \& Larry A. M. (1996). Understanding and using empowerment to change organizational culture. Industrial Management 7 (12) pp 18-27.

Lee, M. \& Chang, S. (2007). A study on relationship among leadership, organizational culture, the operation of learning organization and employees' job satisfaction. The Learning Organization. 14 (2), pp155-185.

Lund, D.B. (2003). Organizational culture and job satisfaction, Journal of Business \& Industrial Marketing, 18(3), pp. 219-236

Macey, W.H., Schneider, B., Barbera, K.M. \& Young, S.A. (2009). Employee Engagement: Tools for Analysis, Practice, and Competitive Advantage. Wiley-Blackwell, Chichester.

Macleod, D. \& Brady, C. (2008). The Extra Mile. How to Engage Your People to Win, PrenticeHall Financial Times, London.

Marcoulides, G.A., \& Heck, R.H. (2009). Organizational Culture and Performance: Proposing and Testing A Model. Organization Science, 4(2), 2009-225.

Martins, E.C. \& Terblanche, F. (2003). Building organizational culture that stimulates creativity and innovation. European Journal of Innovation Management, 6(1), pp. 64-74.

McNeal, G.S. (2010). Organizational Culture, Professional Ethics, and Guantanamo. Case Western Reserve Journal of International Law (2010) 125-149

Musyoka, L. W. (2011). Measures taken to overcome challenges in strategy implementation at 
the Jomo Kenyatta Foundation. International Journal of Current Research. 3(11), 292300.

Mwashighadi G., Kising'u, T., (2017). Role of Organizational Culture on Organizational Performance of Commercial Banks in Kenya: A Case of Commercial Banks in Voi Sub County. The Strategic Journal of Business \& Change Management, 4 (14), pp 241 - 262.

Mwaura N. E. and Bula, H. (2017) Organizational Culture and Firm Performance: A case of the Institute of Certified Public Accountants of Kenya. International Journal of Business, Social Sciences and Education, 10 (3), pp 74-105

Ndwiga, M. (2012). How to Change the Culture of an Organization. Management (8). Kenya Institute of Management publication.

Nongo, E.S. and Ikyanyon, D.N. (2012). The Influence of Corporate Culture on Employee Commitment to the organization. International Journal of Business and Management.7(22);1-8

Ochanda, R. A. (2010). Challenges of strategy implemented at Kenya Industrial Estates Limited. Graduate Research Proposal. Nairobi: UoN.

Ofori, D., \& Atiogbe, E. (2011). Strategic planning in public universities: A developing country perspective. Journal of Management and Strategy, 3(1), 68-85.

Ojo, O (2009). Impact Assessment of Corporate Culture on Employee Job Performance. Business Intelligence Journal - August, 2009 Vol. 2 No. 2

Olughor R. (2014). The Influence of Organizational Culture on Firms' Effectiveness. IOSR Journal of Business and Management. Volume 16, Issue 6. Ver. I, pp 67-70

Omboi, B. M., \& Mucai, P. G. (2012). Factors affecting the implementation of strategic plans in government tertiary institutions: A survey of selected technical training institutes. European Journal of Business and Management. 3(3), 85-105.

O'Reilly, C., Chatman, J. \& Caldwell, D.F. (1991). People and organizational culture: a profile comparison approach to assessing person organization fit. Academy of Management Studies, Vol. 34, pp. 487-516.

Rahid, Md., Sambasivan, A., \& Johari, J. (2003). 2) The influence of corporate culture and organizational commitment on performance. Journal of Management Development. 22(8), p 708-723.

Robbins, S.P. and Judge T.A (2013). Organizational Behavior. Pearson Education, Inc, Prentice Hall

Robertson, I. T., Birch, A. J.\& Cooper, C. L. (2012). Job and work attitudes, engagement and employee performance. Where does psychological well-being fit in? Leadership \& Organization Development Journal Vol. 33 No. 3, 2012 pp. 224-232

Runy, L. A. (2007) "Attributes of a high-performing culture." H\&HN Hospitals \& Health Networks Apr. 2007: 60+. Expanded Academic ASAP. Web. 2 Feb. 2013

Siew, K., Jean, L., \& Yu, K. (2004) Corporate Culture and Organizational Performance. Journal of Managerial Pyschology, Vol. 19 No. 4 pp. 340-349.

Singh, D. and Verghese, M. (2015). Impact of Employee Empowerment on Job Satisfaction And Organizational Commitment. International Journal In Management And Social Science.3(3); 280-286

Sorensen, J.B. (2002). The Strength of Corporate Culture and the Reliability of Firm Performance. Administration Science Quarterly, Vol. 47, No. 1. Pp. 70-91

Steinberg, R. M. (2009) "Corporate culture: who failed, who got it right." Compliance Week Mar. 2009: 38+. Expanded Academic ASAP. 
Sunarsih N. \& Mashithoh H. (2016). The Influence of Organizational Culture Adaptability in Regard to the Organizational Commitment of the Staff of Universitas Terbuka. Review of Integrative Business and Economics Research, Vol. 5, no. 1, pp.199-209.

Toarmina. R. J. (2009). Organizational Socialization: The Missing Link between Employee Needs and Organizational Culture. Journal of Managerial Psychology, 24(7) pp 650- 676 Wines, W. \& Hamilton, J. (2009), On Changing Organizational Culture by Injecting New Idealogies: The Power of Stories. Journal of Business Ethics 89(3) pp 433-447

This is an open-access article published and distributed under the terms and conditions of the $(\mathrm{cc}) \mathrm{EY}$ Creative Commons Attribution 4.0 International License of United States unless otherwise stated. Access, citation and distribution of this article is allowed with full recognition of the authors and the source.

Authors seeking to publish with an International Peer Reviewed Journal should consider https://www.ijcab.org/ by writing to the Editor at editor@ijcab.org. The articles must be quality, in English and meet originality test. 